\title{
ANALISIS SIFAT MEKANIK DAN SIMULASI KEGAGALAN KOMPOSIT SERAT PELEPAH PALEM SADENG MATRIKS POLYPROPYLENE SEBAGAI ATAP MOBIL
}

\author{
Wahyudin $^{1}$, Kardiman ${ }^{2}$, Didis Cahyadi ${ }^{3}$, Al Ichlas Imran ${ }^{4}$ \\ ${ }^{1}$ Jurusan Teknik Industri Fakultas Teknik Universitas Singaperbangsa Karawang \\ 2,3, Jurusan Teknik Mesin Fakultas Teknik Universitas Singaperbangsa Karawang \\ ${ }^{4}$ Jurusan Teknik Mesin Universitas Halu Oleo \\ kardiman@ft.unsika.ac.id
}

\begin{abstract}
ABSTRAK
Telah dilakukan penelitian tentang analisis sifat mekanik dan simulasi kegagalan komposit serat palem sadeng matriks polypropylene sebagai atap mobil yang disimulasikan menggunakan software Inventor Professional 2014. Penelitian ini diharapkan dapat memberi informasi hasil pengujian sifat mekanik dan sifat fisis serat palem sadeng dengan perekat polypropylene serta mengetahui hasil simulasi kegagalan dalam stress analysis test menggunakan software Inventor Professional 2014. Papan komposit dibuat menggunakan metode hot press dengan tiga variasi fraksi volume yaitu $20 \%$ serat: $80 \%$ matriks, $30 \%$ serat: $70 \%$ matriks dan $40 \%$ serat: $60 \%$ matriks. Karakterisasi sifat fisis komposit berupa densitas, sedangkan sifat mekanik berupa pengujian tarik. Hasil pengujian fisis komposit menunjukkan bahwa komposit yang dibuat sesuai dengan klasifikasi JIS A5908 (2003). Hasil pengujian tarik komposit menunjukkan bahwa nilai kekuatan tarik maksimal yang paling besar diperoleh pada fraksi volume $40 \%$ serat: $60 \%$ matriks dengan nilai 18,53 $\mathrm{MPa}$, diikuti penurunan kekuatan tarik pada fraksi volume 30\% serat: $70 \%$ matriks dan $20 \%$ serat: $80 \%$ matriks. Meningkatnya kekuatan tarik dikarenakan adanya penambahan fraksi volume serat. Selanjunya, dilakukan simulasi kegagalan berdasarkan menggunakan software Inventor Professional 2014. Simulasi kegagalan menggunakan tiga variasi pembebanan yaitu $75 \mathrm{~kg}, 100 \mathrm{~kg}$ dan $125 \mathrm{~kg}$. Hasil simulasi kegagalan berdasarkan static test dari ketiga variasi kecepatan tersebut menunjukkan nilai von misses stress dibawah nilai yield strength yang dimiliki material, kemudian nilai displacement yang terjadi kecil serta nilai safety factor yang dihasilkan yaitu di atas satu.
\end{abstract}

Kata kunci: komposit, serat palem sadeng, polypropylene, kekuatan tarik, simulasi kegagalan

\section{ABSTRACT}

Analysis Of Mechanical Properties And Simulation Of Failure Composites Of Fiber Palem Plastic Matrix Polypropylene As A Car Roof. Research on the analysis of mechanical properties and simulation of sadeng polypropylene palm fiber composite as a car roof was denied using Inventor Professional software 2014. This study is expected to provide information on the results of research on the mechanical properties and physical properties of sadeng palm fibers using polypropylene and the results of testing failed stress analysis test using Inventor Professional software 2014. Composite boards were made using the hot press method with three variations in volume fraction namely 20\% fiber: $80 \%$ matrix, 30\% fiber: $70 \%$ matrix and 40\% fiber: $60 \%$ matrix. The characteristics of the combined physical properties consist of density, while the mechanical properties consist of tensile testing. The test results are made according to the JIS A5908 (2003) classification. The combined tensile test results reported that the maximum tensile rating obtained was obtained at a volume fraction of $40 \%$ fiber: $60 \%$ matrix with a value of 18.53 $\mathrm{MPa}$, followed by withdrawal of tensile strength at a volume fraction of 30\% fiber: $70 \%$ frame and $20 \%$ fiber: $80 \%$ matrix. Increased tensile strength due to the volume of fiber. Next, a simulation of failure using the Inventor Professional software 2014. Simulation failed to use three variations of loading, namely $75 \mathrm{~kg}, 100 \mathrm{~kg}$ and $125 \mathrm{~kg}$. The simulation results fail based on the static test of the three speed variations indicating the von value misses the stress below the value of the material possessed, then the displacement value that occurs is small and the value of the safety factor produced above one.

Keywords: composite, sadeng palm fiber, polypropylene, tensile strength, failure simulation

\section{PENDAHULUAN}

Perkembangan teknologi dalam sektor industri otomotif membutuhkan material dengan sifat kuat dan ringan sebagai pengganti material logam. Hal ini telah mendorong perkembangan material baru yang 
disebut material komposit. Material komposit mempunyai beberapa kelebihan berbanding dengan bahan konvensional seperti logam. Kelebihan tersebut pada umumnya dapat dilihat dari beberapa sudut yang penting seperti sifat-sifat mekanikal dan fisikal, mudah dalam proses pembentukan dan biaya [1]. Komposit banyak dikembangkan karena memiliki sifat yang diinginkan karena tidak didapat dari material lain apabila berdiri sendiri. Komposit pada umumnya tersusun dari material pengikat (matrik) dan material penguat yang disebut juga material pengisi (filler) [2].

Seiring perkembangan teknologi bahan tersebut, banyaknya komposit polimer serat alam mulai tergantikan oleh jenis bahan serat sintesis, seperti: gelas, karbon, rayon, akril, dan nilon [3]. Namun, penggunaan serat sintetis sebagai penguat komposit memiliki dampak negatif pada lingkungan karena limbahnya tidak dapat terurai secara alami dan dapat mengganggu hingga beberapa generasi. Penggunaan serat alami sebagai penguat komposit merupakan langkah bijak, mengingat untuk serat alami dapat terurai secara alami, dan banyak ragam serat alami yang tersedia misalnya serat goni, serat nanas, serat ijuk, serat sabut kelapa, dan lain - lain [4].

Palem sadeng (Livistona rotundifolia) merupakan tanaman hias dengan daun yang unik karena berbentuk seperti kipas dan batangnya tumbuh tegap ke atas. Pelepah palem sadeng yang jatuh atau rontok ketika pelepah palem sadeng semakin tua belum dimanfaatkan secara maksimal dan hanya terbuang sebagai limbah. D. Maureen (2015) menyatakan pemanfaatan pelepah palem masih kurang dan bahkan belum di olah lebih banyak dan lebih dalam [5].

Pada penelitian ini menggunakan serat pelepah palem sadeng sebagai filler yang terlebih dahulu melalui proses treatment seperti scouring dan bleaching yang dapat meningkatkan kekuatan mekanik. Penelitian Wijayanti (2015) menyatakan treatment scouring dan bleaching serta penambahan fraksi volume dapat meningkatkan kekuatan mekanik komposit [6,7].

Penelitian yang telah dilakukan Hernandar (2004), serta Rusmiyatno (2007) menyatakan bertambahnya fraksi volume serat dapat meningkatkan kekuatan tarik komposit [7]. Jenis pengikat yang digunakan adalah polypropelene. Polypropelene merupakan salah satu thermoplastik yang mudah di difabrikasi dengan serat alam. Polypropylene adalah jenis matriks yang dapat digunakan diberbagai bidang polymer matrix composite (PMC) diantaranya bidang electric, packaging, dan otomotif [8].

Komposit serat palem matrik polypropelene akan diaplikasikan untuk pembuatan atap mobil. Atap mobil dalam perencanaannya harus terdapat berbagai kelebihan - kelebihan yang dapat diperoleh dari hasil design virtual, maka dari itu perencanaan keunggulan dari yang diproduksi memiliki tiga kelebihan utama antara lain faktor keamanan yang terjamin, berat yang semakin ringan, serta biaya produksi yang lebih murah [9]. Untuk mengetahui kekuatan dan perilaku mekanik komposit yang akan diaplikasikan sebagai atap mobil perlu dilakukan pengujian lebih lanjut. Adapun metode pengujian yang akan dilakukan adalah dengan memberikan variasi pembebanan yang kemudian disimulasikan dengan menggunakan software Autodesk Inventor Professional 2014 dikomputer. Simulasi menggunakan software bertujuan untuk mendapatkan distribusi tegangan sebagai perilaku mekanik komposit serat palem matrik polypropylene.

Dari uraian diatas, peneliti tertarik untuk meneliti beberapa sifat fisik dan sifat mekanik komposit berpenguat serat alam, yaitu serat pelepah palem sadeng matriks polypropylene(PP) metode yang digunakan yakni metode hot press dan di simulasi menggunakan Software Inventor Autodesk Professional 2014.

\section{METODE PENELITIAN}

Penelitian ini menggunakan metode eksperimental dan simulasi menggunakan autodesk inventor professional 2014. Penelitian dilaksanakan di Laboratorium Ilmu Dasar Fakultas Teknik Universitas Singaperbangsa Karawang dan Balai Besar Bahan dan Barang Teknik (B4T) Bandung.

\subsection{Alat dan Bahan Penelitian}

Alat yang digunakan pada saat pencetakan papan komposit adalah Mesin Hot Press. Mesin Hot Press (Lab Produksi Teknik Mesin Universitas Singaperbangsa Karawang) merupakan alat yang dibuat peneliti sebelumnya [10], yang berfungsi sebagai alat untuk membuat papan komposit dengan 
cara memadatkan matriks dan serat menggunakan sistem hidrolik penekan panas. Mesin hot press seperti yang ditunjukan pada Gambar 1 memiliki bagian-bagian utama antara lain:

1. Panel listrik,

2. Dise atas,

3. Dise bawah,

4. Pressure gauge,

5. Tuas pompa, dan

6. Pompa hidrolik.

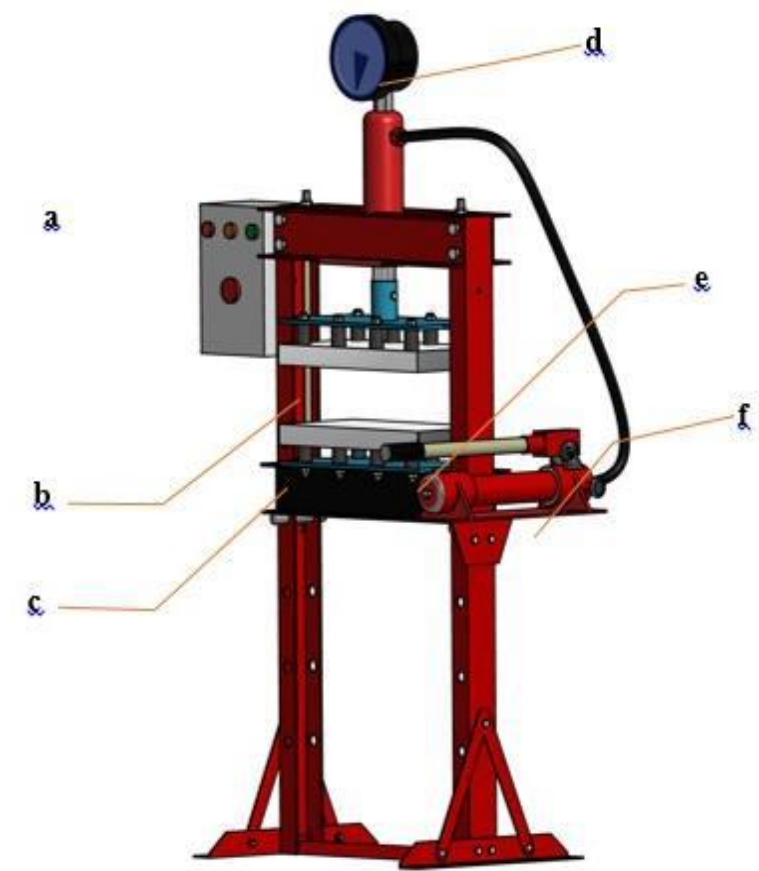

Gambar 1. Mesin Hot Press

Bahan-bahan yang digunakan untuk pembuatan komposit serat pelepah palem sadeng matriks polypropylene adalah sebagai berikut:

1. Serat Pelepah Palem Sadeng

2. Polypropylene

3. Alumunium foil, dan

4. Wax mold release.

\subsection{Perlakuan Terhadap Serat}

Serat palem berukuran $10 \mathrm{~cm}$ dan direndam kedalam air, selama 24 jam kemudian di dikeringkan, di bawah sinar matahari. Proses scouring, dilakukan dengan cara merendam serat palem sadeng pada larutan $\mathrm{Mn} \mathrm{NaOH} \mathrm{20gr/l} \mathrm{+} \mathrm{teepol} 2$ gr/l + aquades 1 liter selama 1 jam pada suhu $100^{\circ} \mathrm{C}$ dengan tujuan untuk mengurangi kandungan ligninnya dan selulosa yang menempel pada serat. Setelah proses scouring serat palem sadeng dibersihkan dengan aquades yang mengalir sampai serat netral dan dijemur dibawah sinar matahari hingga struktur serat mengering.

\subsection{Pembuatan Papan Komposit}

Pembuatan komposit diawali dengan mempersiapkan bahan berupa serat palem sadeng yang sudah mengalami proses treatment dan biji plastik polypropylene. Fraksi volume komposit yang digunakan dalam penelitian ini sebagai berikut:

1. $20 \%$ serat $+80 \%$ matrisk

2. $30 \%$ serat $+70 \%$ matriks

3. $40 \%$ serat $+60 \%$ matriks

Perhitungan komposit berdasarkan perhitungan volume total cetakan. Pencetakan papan komposit berukuran 20 × 5,5 x 0,4 $\mathrm{cm}^{3}$. Papan komposit dicetak selama 2 jam menggunaka mesin hot press Gambar 1 dengan tekanan \pm

Cetakan di tutup dengan menggunakan lempengan besi yang dilapisi aluminium foil dan diletakkan pada kempa panas (hot press) kemudian ditekan untuk mendapatkan ketebalan komposit yang sesuai dengan cetakan pada suhu $200^{\circ} \mathrm{C}$ selama 2 jam. Kemudian papan komposit dikeluarkan dari cetakan dan didinginkan dengan suhu ruang. Dilakukan seperti sampel 1 untuk pembuatan sampel 2 dan sampel 3. Papan komposit yang sudah dingin dipotong dan dibentuk sesuai standar ASTM D 638.

\subsection{Pengujian Papan Komposit}

Setelah papan komposit selesai dibuat, maka dilakukan beberapa pengujian yang terdiri dari:

\section{a. Pengujian Fisis Komposit}

Papan komposit yang telah dingin dipotong sesuai standar JIS A5908 (2003), ditimbang menggunakan timbangan digital dan diukur panjang, lebar, serta ketebalan di lima titik yang telah ditandai menggunakan calliper. Setelah pengukuran, sampel uji direndam dalam air selama dua puluh empat jam dengan ketinggian permukaan air sebesar $3 \mathrm{~cm}$ dari permukaan sampel uji, selanjutnya diukur kembali massa, panjang, lebar, dan ketebalan di lima titik setelah proses perendaman.

b. Pengujian Tarik

Pengujian tarik dilakukan di Balai Besar Bahan dan Barang Teknik (B4T) Bandung, dengan 
mesin uji tarik Tensilon dengan kapasitas 2000 $\mathrm{kg}$, kecepatan dapat divariasikan. Spesimen uji tarik menggunakan standar ASTM D638.

\section{c. Simulasi Kegagalan}

Data hasil pengujian komposit dimasukkan ke software autodesk Inventor Professional 2014 pada program Stress Analysis. Pengaplikasian komposit dalam penelitian ini yaitu pada atap mobil listrik Teknik Mesin Unsika.

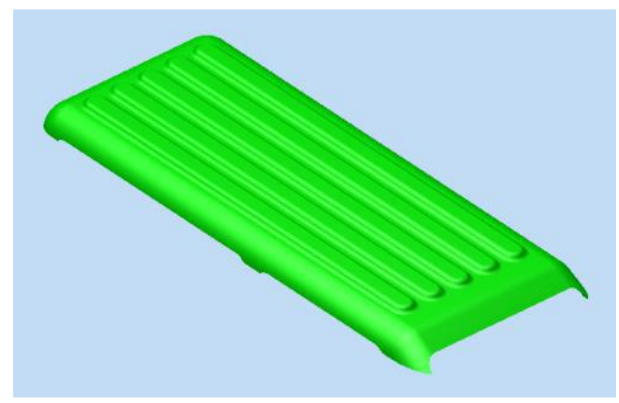

Gambar 2. Desain Atap Mobil Listrik

\section{HASIL DAN PEMBAHASAN}

Hasil pengujian dianalisis untuk mendapatkan sifat mekanik dan kegagalan yang terjadi pada spesimen uji. Distribusi tegangan yang terjadi akibat pembebanan pada atap mobil akan menghasilkan nilai beban maksimal yang dapat diterima atap mobil dengan cara simulasi.

\subsection{Hasil Pembuatan Papan Komposit}

Dari hasil pembuatan papan komposit maka diperoleh papan komposit dengan dimensi panjang (p) $20 \mathrm{~cm}$, lebar (1) $5,5 \mathrm{~cm}$ dan tinggi/tebal (t) 0,5 $\mathrm{cm}$, dengan variasi komposit $20 \%$ serat : $80 \%$ matriks, $30 \%$ serat dan $70 \%$ matriks, $40 \%$ serat dan $60 \%$ matriks seperti terlihat pada Gambar 3 .

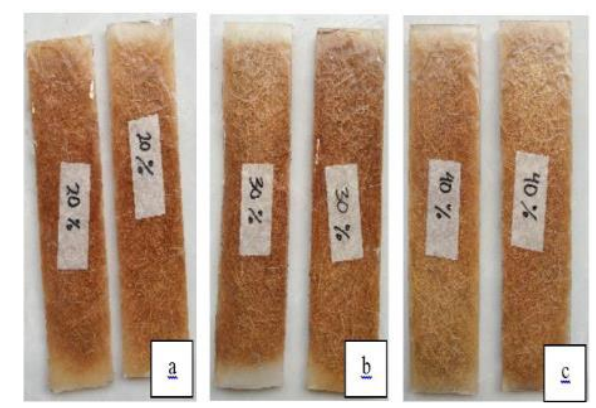

Gambar 3. Hasil Pencetakan Papan Komposit
Papan komposit $20 \%$ serat dan $80 \%$ polypropylene seperti pada gambar 0.1 (a) terdapat banyak rongga udara kecil pada semua bagian sisi. Pada papan komposit $30 \%$ serat dan $70 \%$ polypropylene rongga udara terbanyak terdapat pada bagian bawah. Papan komposit $40 \%$ serat dan $60 \%$ polypropylene masih terdapat rongga udara pada semua sisi. Dari semua spesimen, hampir semua papan komposit terdapat rongga udara.

\subsection{Pengujian Fisis dan Mekanik Komposit}

Papan komposit yang dicetak dengan menggunakan metode hot press dengan fraksi volume $20 \%$ serat dan $80 \%$ polypropylene, $30 \%$ serat dan $70 \%$ polypropylene, $40 \%$ serat dan $60 \%$ polypropylene. Pengujian fisis pada penelitian ini yaitu pengujian densitas dengan menggunakan standar JIS A5908 (2003), sedangkan pengujian mekanik pada penelitian ini yaitu pengujian tarik dengan menggunakan standar ASTM D638 untuk menentukan kekuatan tarik maksimal, kekuatan luluh dan modulus elastisitas.

\section{Pengujian Fisis}

Densitas komposit menunjukkan sifat ringan pada bahan komposit. Semakin kecil nilai densitas komposit maka semakin ringan komposit tersebut. Prosedur pengujian menggunakan standard JIS A5908. Hasil pengujian fisis komposit serat palem sadeng matrik polypropylene yaitu: Berdasarkan data-data hasil pengujian kerapatan papan komposit berkisar $0,69 \mathrm{gr} / \mathrm{cm}$ sampai $0,74 \mathrm{gr} / \mathrm{cm}$. Hasil pengujian tersebut menunjukkan bahwa papan komposit dengan perbandingan $30 \%$ serat : $70 \%$ matrik mempunyai nilai kerapatan tertinggi sedangkan papan komposit dengan perbandingan $20 \%$ serat : $80 \%$ matrik mempunyai nilai kerapatan terendah.

2. Pengujian mekanik

Pengujian kekuatan tarik pada komposit serat palem sadeng dengan fraksi volume $20 \%$ serat: $80 \%$ matriks, $30 \%$ serat: $70 \%$ matriks, $40 \%$ serat: $60 \%$ matriks dapat disimpulkan bahwa terdapat perbedaan hasil kekuatan tarik maksimal, kekuatan luluh dan modulus elastisitas. Kekuatan tarik maksimal dan kekuatan luluh menghasilkan nilai yang sama pada semua fraksi volume. 


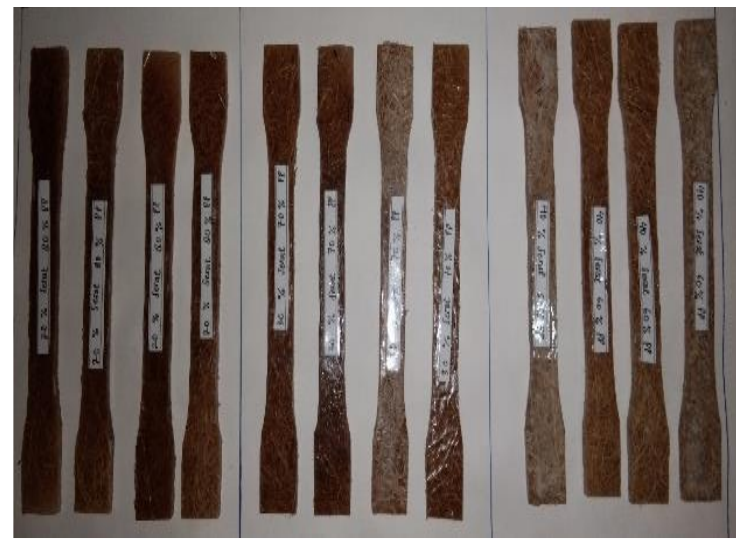

Gambar 4. Sampel Uji Tarik

a. Kekuatan Tarik

Kekuatan tarik meningkat seiring penambahan volume serat. Pada fraksi volume $20 \%$ serat : $80 \%$ matriks kekuatan tarik paling besar yaitu 9,91 MPa. Pada fraksi volume 20\% serat : $80 \%$ matriks kekuatan tarik paling besar yaitu 13,59 MPa. Pada fraksi volume $40 \%$ serat : $60 \%$ matriks kekuatan tarik paling besar yaitu 18,53 MPa.

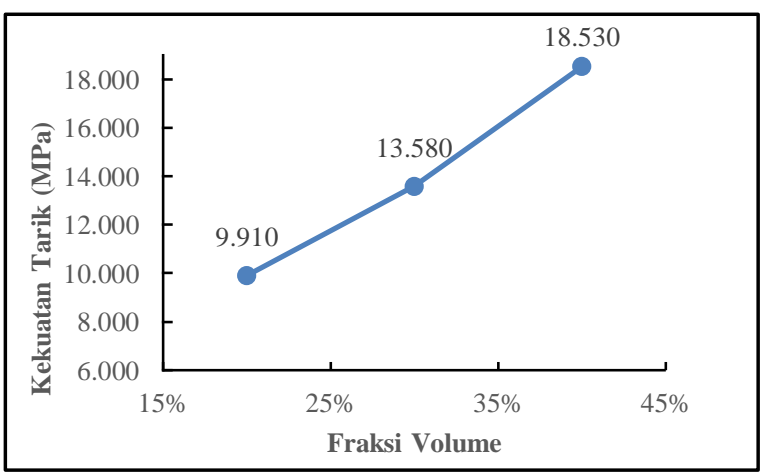

Gambar 5. Grafik Hasil Uji Kekuatan Tarik

Berdasarkan Gambar 5 Garafik hasil uji tarik menunjukan kekuatan tarik terbesar yaitu pada komposit dengan fraksi volume 40\% serat : $60 \%$ matriks sebesar 18,53 MPa. Penambahan komposisi serat dapat meningkatkan kekuatan tarik seperti pada penelitian Hernandar (2004) tentang pengaruh fraksi volume serat pada sifat mekanis komposit unsaturated polyester yang diperkuat serat kenaf menyatakan bahwa KFRP mengalami peningkatan kekuatan tarik dan modulus elastisitas seiring dengan bertambahnya fraksi volume serat [11]. Kemudian pada penelitian yang dilakukan oleh Rusmiyatno (2007) tentang pengaruh fraksi volume serat terhadap kekuatan tarik dan kekuatan bending komposit nylon/epoxy resin serat pendek random memiliki kekuatan maksimal 26,13 MPa dengan fraksi volume $60 \%$ serat $40 \%$ matriks [12]. Pada fraksi volume $30 \%$ serat: $70 \%$ matrik mengalami penurunan kekuatan tarik. Nilai kekuatan tarik fraksi volume $30 \%$ serat: $70 \%$ matriks yaitu 13,59 MPa. Pada fraksi volume $20 \%$ serat: $80 \%$ matriks juga mengalami penurunan. Nilai kekuatan tarinya yaitu sebesar 9,91 MPa.

b. Kekuatan luluh

Gambar 6. Grafik Hasil Uji Kekuatan Luluh terlihat kekuatan luluh tertinggi pada fraksi volume $40 \%$ serat: $60 \%$ matriks yaitu $18,53 \mathrm{MPa}$. Pada fraksi volume 30\% serat: $70 \%$ kekuatan luluhnya yaitu 13,59 MPa. Fraksi volume $20 \%$ serat: $80 \%$ yaitu $9,91 \mathrm{MPa}$.

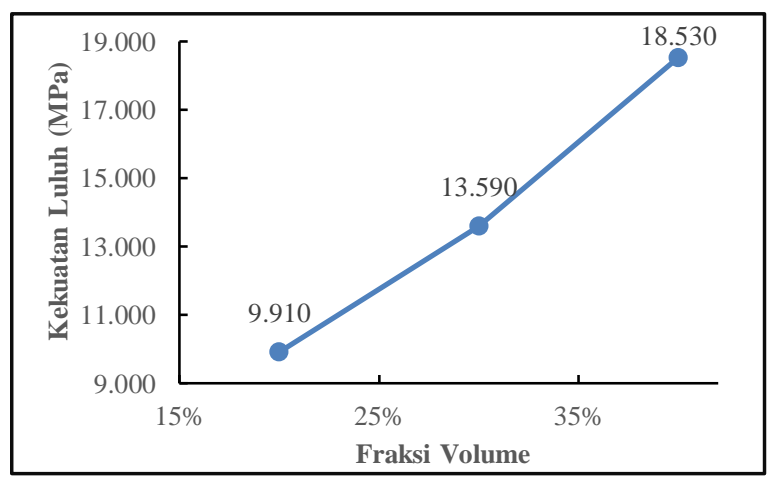

Gambar 6. Grafik Hasil Uji Kekuatan Luluh

c. Modulus Elastisitas

Kekuatan luluh dari tiap-tiap fraksi volume diketahui pada fraksi volume 20\% serat: $80 \%$ matriks modulus elastisitas yaitu 990,55 MPa. Pada fraksi $30 \%$ serat: $70 \%$ modulus elastisitasnya yaitu 2589,70 MPa. Pada fraksi volume $40 \%$ serat: $60 \%$ modulus elastisitasnya 16985,00 MPa.

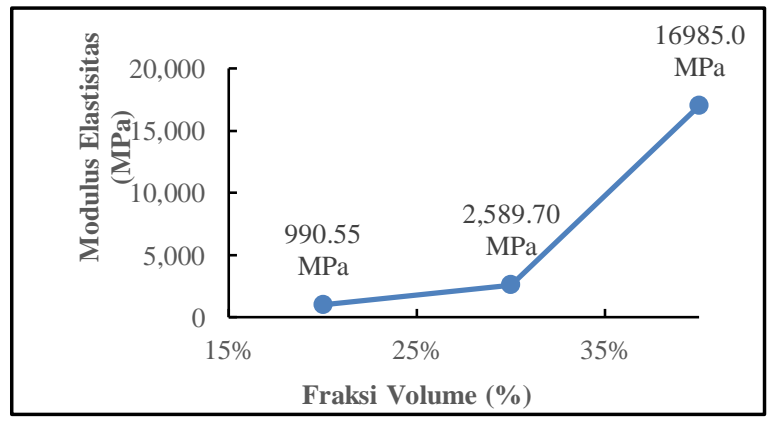

Gambar 7. Grafik Hasil Uji Modulus Elastisitas 
Berdasarkan Gambar 7 grafik hasil uji modulus elastisitas terlihat modulus elastisitas tertinggi pada fraksi volume $40 \%$ serat: $60 \%$ matriks yaitu 16985,00 MPa. Modulus elastisitas pada fraksi volume $30 \%$ serat: $70 \%$, nilai modulusnya yaitu 258,59 MPa. Penurunan nilai modulus paling banya di dapat pada fraksi volume 20\% serat: $80 \%$ matriks, nilai modulusnya yaitu $990,55 \mathrm{MPa}$.

\subsection{Hasil Simulasi Kegagalan}

Hasil simulasi stress analisys komposit serat palem matrik polypropylene pada atap mobil dengan variasi pembebanan $75 \mathrm{~kg}, 100 \mathrm{~kg}$ dan $125 \mathrm{~kg}$ dengan percepatan gravitasi $9,8 \mathrm{~m} / \mathrm{s}^{2}$ yaitu berupa von misses stress, stress, displacemment, dan safety factor yang akan di jelaskan sebagai berikut dijelaskan sebagai berikut:

\section{Von misses}

Hasil von misses stress pada simulasi stress analisys dengan variasi pembebanan sebesar 75 $\mathrm{kg}, 100 \mathrm{~kg}$ dan $125 \mathrm{~kg}$ dilihat dari Gambar 8Gambar 10.

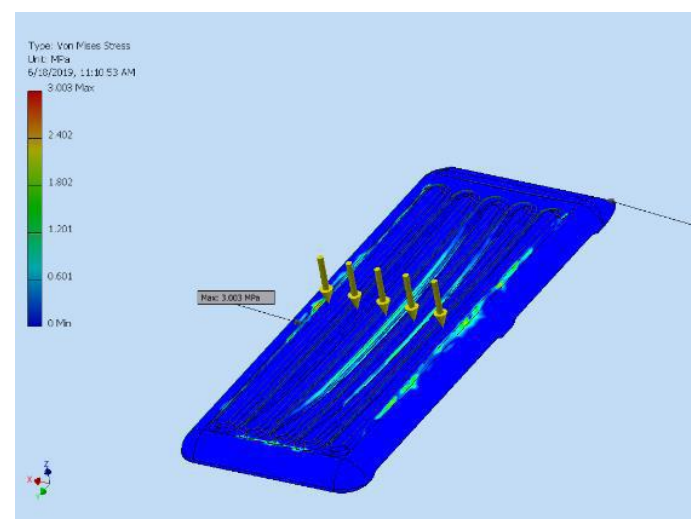

Gambar 8. Hasil von mises stress $75 \mathrm{~kg}$

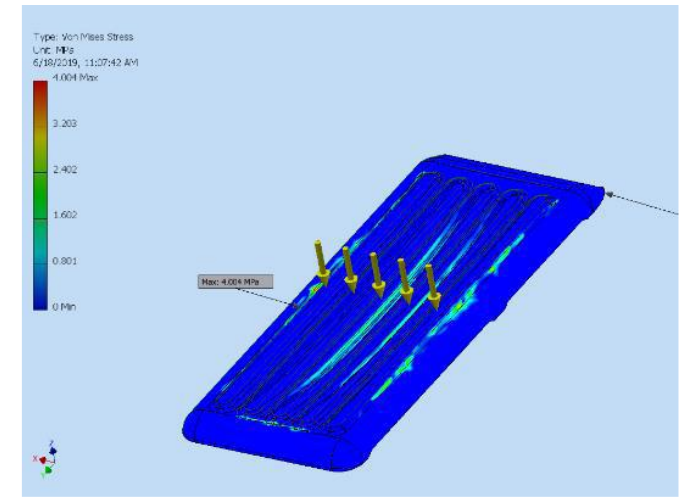

Gambar 9. Hasil von mises stress $100 \mathrm{~kg}$

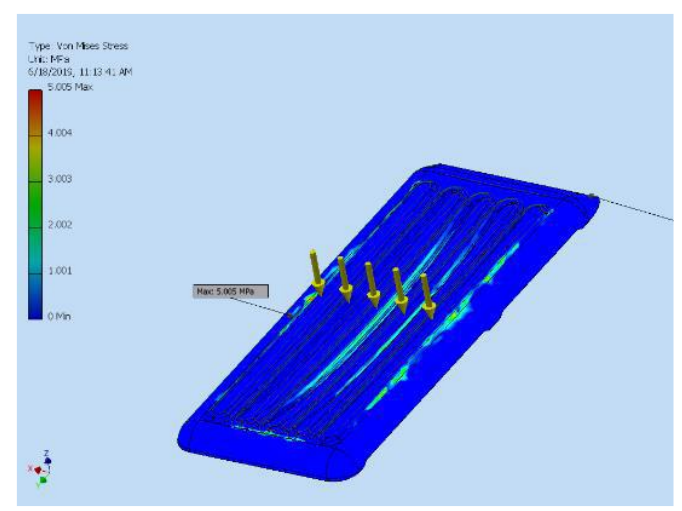

Gambar 10. Hasil von mises stress $125 \mathrm{~kg}$

Dari gambar diatas disimpulkan bahwa von misses terkecil yaitu pada variasi beban $75 \mathrm{~kg}$ yaitu 3,003 MPa, sedangkan von misses terbesar pada variasi beban $125 \mathrm{~kg}$ yaitu 5,005 MPa.

Von mises aman atau tidak amannya dapat menggunakan hasil analisis, dimana jika tegangan von mises lebih kecil dari yield strength maka material yang digunakan dapat dikatakan aman [13].

\section{Displacement}

Displacement adalah perubahan bentuk pada bagian yang dikenai gaya. Hasil analisys displacement dengan variasi pembebanan sebesar $75 \mathrm{~kg}, 100 \mathrm{~kg}$ dan $125 \mathrm{~kg}$ dilihat dari Gambar 11Gambar 13. 


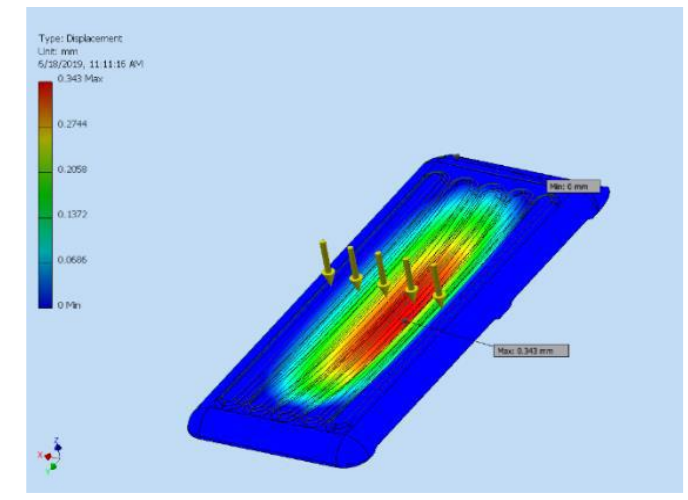

Gambar 11. Hasil analisis displacement $75 \mathrm{~kg}$

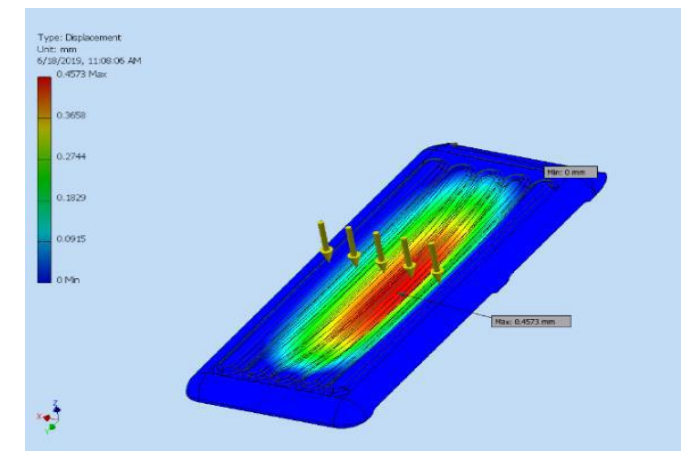

Gambar 12. Hasil analisis displacement $100 \mathrm{~kg}$

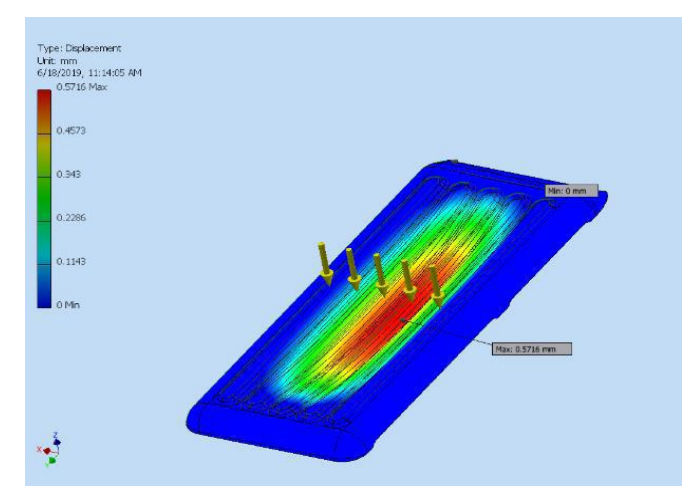

Gambar 13. Hasil analisis displacement $125 \mathrm{~kg}$

Displacement yang terjadi pada setiap variasi berbeda-beda hasil analisisnya. Dari Gambar 11 Gambar 12 dapat disimpulkan bahwa displacemen minimum pada variasi beban $75 \mathrm{~kg}$ yaitu $0,343 \mathrm{~mm}$, sedangkan displacement maksimum pada variasi beban $125 \mathrm{~kg}$ yaitu $0,5716 \mathrm{~mm}$.

\section{Safety factor}

Safety factor atau faktor keamanan adalah faktor yang digunakan untuk mengevaluasi kemanan suatu struktur, dimana kekuatan suatu bahan harus melebihi kekuatan sebenarnya. Hasil analisis Safety factor dengan variasi pembebanan sebesar $75 \mathrm{~kg}, 100 \mathrm{~kg}$ dan $125 \mathrm{~kg}$ dapat dilihat pada Gambar 14 - Gambar 16.

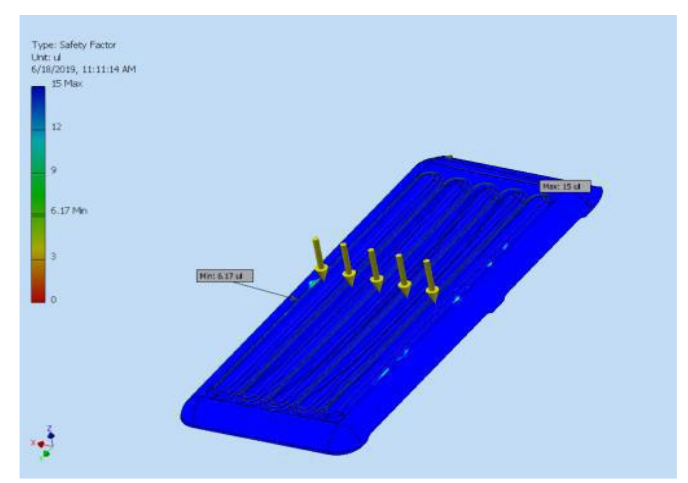

Gambar 14. Hasil analisys Safety factor $75 \mathrm{~kg}$

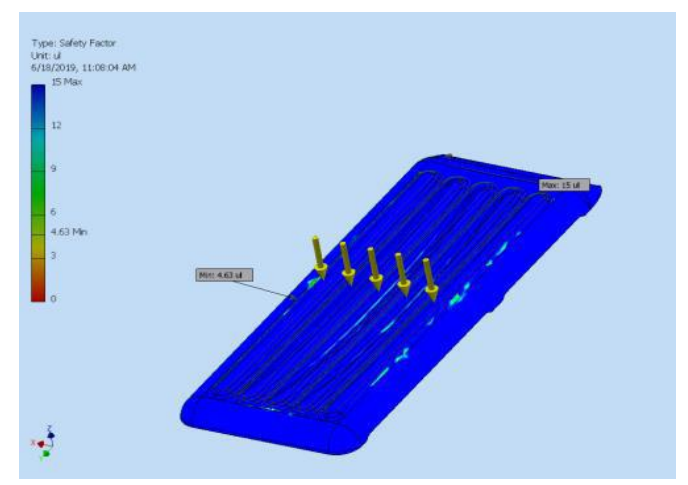

Gambar 15. Hasil analisys Safety factor $100 \mathrm{~kg}$

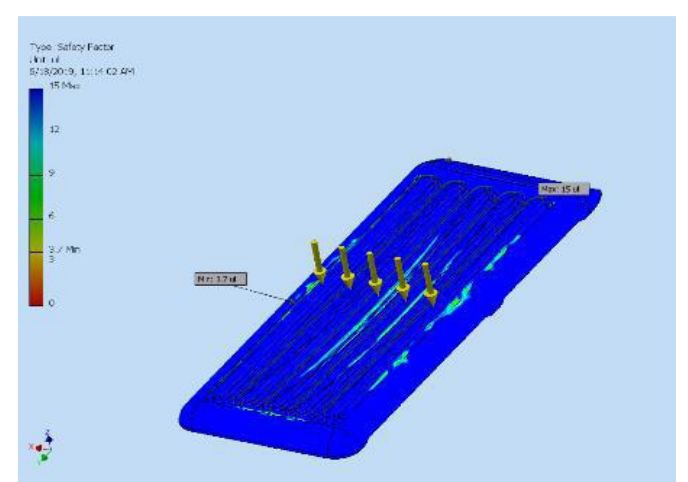

Gambar 16. Hasil analisys Safety factor $125 \mathrm{~kg}$

Safety factor yang terjadi pada setiap variasi berbeda-beda hasil analisisnya. Berdasarkan Gambar 14 - Gambar 16 dapat ditunjukkan bahwa Safety factor minimum pada variasi beban $750 \mathrm{~kg}$ yaitu 6,17 ul, sedangkan displacement maksimum pada 
variasi beban $125 \mathrm{~kg}$ yaitu $3,7 \mathrm{ul}$. Safety factor adalah factor keamanan dari suatu material atau bahan. Keamanan dapat dihitung sebagai kekuatan luluh dari materi yang di bagi dengan tegangan tarik. Faktor keamanan kurang dari 1 menunjukan bahwa material tersebut aman untuk digunakan[14].

\section{KESIMPULAN}

Dari hasil penelitian komposit serat palem sadeng matriks polypropylene yang dilakukan maka didapat kesimpulan sebagai berikut: Hasil pengujian fisis pada komposit serat pelepah palem sadeng matriks polypropylene memiliki kerapatan yang medium dengan nilai kerapatan terbesar terdapat pada sampel $30 \%$ serat : 70 polypropylene yaitu $0,74 \mathrm{~g} / \mathrm{cm}$, dan hasil terendah pada sampel $20 \%$ serat: 70 polypropylene yaitu $0,64 \mathrm{~g} / \mathrm{cm}$. Hasil pengujian mekanik komposit serat pelepah palem sadeng matriks polypropylene pengujian tarik terbesar terdapat pada sampel sampel $40 \%$ serat: 60 polypropylene yaitu $18,53 \mathrm{MPa}$. Tegangan luluh terbesar yaitu pada sampel $40 \%$ serat: 60 polypropylene sebesar $18,53 \mathrm{MPa}$, dan nilai modulus elastisitas terbesar yaitu pada sampel $40 \%$ serat: 60 polypropylene sebesar 16242,00 MPa. Hasil simulasi kegagalan menggunakan software Autodesk Inventor Professional 2014 dengan variasi pembebanan 75 $\mathrm{kg}, 100 \mathrm{~kg}$ dan $125 \mathrm{~kg}$, nilai von misses stress terbesar yaitu pada variasi beban $125 \mathrm{~kg}$ dan tidak melebihi nilai kekuatan luluh. Sehingga komposit pada penelitian ini layak untuk diuji lebih lanjut. Kemudian hasil displacemen minimum yaitu pada variasi beban $75 \mathrm{~kg}$ yaitu $0,343 \mathrm{~mm}$, sedangkan displacement maksimum pada variasi beban $125 \mathrm{~kg}$ yaitu $0,5716 \mathrm{~mm}$.

\section{DAFTAR PUSTAKA}

[1]. Fadli, I., Ariawan, D., Surojo, E., \& Triyono, J. (2017). Pengaruh Fraksi Volume Serat Terhadap Kekuatan Mekanik Komposit Rhdpe Dengan Penguat Serat Pelepah Salak. Prosiding SNST Fakultas Teknik, 1(1).

[2]. Dharmawan, M. F. (2015). Pemanfaatan Material Alam Pelepah Palem Menjadi Bahan Benda Produk. CALYPTRA, 4(1), 1-19.

[3]. Astutin Dwi, Wijayanti. (2013). Peningkatan Tipe Komposit Kenaf Polypropylene
Berdasarkan JIS A5908 (2003) Dengan Perlakuan Scouring, Bleaching dan Ultrasonic. Yogyakarta: Program Studi Fisika Jurusan Fisika Fakultas Matematika Dan Ilmu Pengetahuan Alam Universitas Gadjah Mada.

[4]. Putra, dkk. (2017).Karakterisasi Sifat -sifat Tarik Komposit Laminat Hibrida Kenaf/Eglass Yang Difabrikasi Dengan Matriks Polypropylene Program Studi Teknik Mesin, Fakultas Teknik, Universitas Muhammadiyah Yogyakarta.

[5]. Harapahap, a. yakub, 2014. Eksperimen Dan Simulasi Ansys 14.0 Kekuatan Impak Jatuh Bebas Pada Struktur Atap Mobil Dari Bahan Komposit Polymeric Foam Diperkuat Serat Tandan Kosong Kelapa Sawit. Medan : Program Pendidikan Sarjana Ekstensi Fakultas Teknik Universitas Sumatera Utara.

[6]. Widiarta, dkk, 2017. Pengaruh Orientasi Serat Terhadap Sifat Mekanik Komposit Berpenguat Serat Alam Batang Kulit Waru (Hibiscus Tiliaceust) Tengan Matrik Polyester. Jurusan Pendidikan Teknik Mesin Universitas Pendidikan Ganesha.

[7]. Suratma ,dkk. 2016. Pengaruh Fraksi Volume Serat Terhadap Sifat Mekanis Komposit Matriks Polimer Polyester Diperkuat Serat Pelepah Gebang Pendidikan Teknik Mesin, Fakultas Teknik Dan Kejuruan, Universitas Pendidikan Ganesha,

[8]. Lubis, F dan, M Yani, 2018, Pembuatan Dan Penyelidikan Perilaku Mekanik Komposit Diperkuat Serat Limbah Plastik Akibat Beban Lendutan. Program Studi Teknik Mesin Fakultas Teknik Universitas Muhammadiyah Sumatera Utara.

[9]. Hasri dkk, 2015. Karakteristik Kekuatan Bending Dan Kekuatan Tekan Komposit Serat Hybrid Kapas/Gelas Sebagai Pengganti Produk Kayu. Jurusan Teknik Mesin Fakultas Teknik Universitas Mataram.

[10]. Hanifi, R. (2019). Rancang Bangun Mesin Hotpress Untuk Pembuatan Papan Komposit Berbasis Limbah Sekam Padi Dan Plasik Hdpe. Gorontalo Journal of Infrastructure and Science Engineering, 2(1), 38-44.

[11]. Hernandar, Wisnu. 2004 Pengaruh Fraksi Volume Serat Pada Sifat Mekanis Komposit 
Unsaturated Polyester Yang Diperkuat Serat

Kenaf. Surakarta : Jurusan Teknik Mesin

Fakultas Teknik Universitas Sebelas Maret.

[12]. Rusmiyatno. 2007. Pengaruh Fraksi Volume Serat Terhadap Kekuatan Tarik Dan Kekuatan Bending Komposit Nylon/Epoxy Resin Serat Pendek Random. Fakultas Teknik Universitas Negeri Semarang.

[13]. Nayiroh, Nurul. 2013. Klasifikasi Komposit Metal Matrix Composite. Teknologi Material Komposit: Indonesia.

[14]. Wasyarahil, Zulfa.i, 2017 Karakterisasi Dan Proses Manufaktur Komposit Polypropylene Berpenguat Serat Dendrocalamus Asper Untuk Aplikasi Ruang Mesin Otomotif. Fakultas Teknologi Industri, Institut Teknologi Sepuluh Nopember. 